УДК 336.225.6; 35.078

DOI https://doi.org/10.32837/yuv.v0i3.2193

\author{
М. Міхровська, \\ кандидат юридичних наук, \\ асистент кафедри адміністративного права та процесу \\ Інституту права \\ Київського національного університету імені Тараса Шевченка
}

\title{
ЦИФРОВА ТРАНСФОРМАЦІЯ ДЕРЖАВИ ЯК НОВИЙ ЕТАП АДМІНІСТРАТИВНОЇ РЕФОРМИ
}

\begin{abstract}
Адміністративна
в Україні - це явище загальнодержавного характеру, значення якого важко переоцінити. Цей процес перманентного реформування триває вже близько 24-х років, проте актуальність його сьогодні не менша, ніж на початку. Так, майже від моменту прийняття Основного Закону Украіна стала на довгий і тернистий шлях перетворень та трансформацій, що триває й досі.

Проте постає питання: чому Україна досі не завершила це реформування та на якому етапі воно знаходиться сьогодні? Для відповіді на це й на інші питання необхідно з'ясувати, яким саме явищем є адміністративна реформа загалом і здійснити періодизацію адміністративної реформи нашої держави та проаналізувати ті кроки, які вже були втілені в життя.
\end{abstract}

Як правило, адміністративна реформа визначається як форма структурного впорядкування, вдосконалення та розвитку системи органів державної влади як єдиного механізму держави, що утворився на основі інтеграції матеріальних, фінансових та людських ресурсів, підприємств, установ, організацій та відповідної ix взаємодії, заснованої на принципах розподілу влади в межах чинного законодавства, що забезпечує виконання завдань та функцій держави, це неперервний у часово-просторовому форматі процес щодо вдоскона- лення інституційних засад механізмів державотворення та державного апарату, результатом якого $€$ соціально-економічний розвиток країни [1, с. 150]. За своїм змістом адміністративна реформа $€$ комплексом політико-правових заходів, які полягають у структурних, функціональних та державно-службових перетвореннях, насамперед у сфері виконавчої влади, 3 метою перетворення іï з владно-репресивного механізму на організацію, що служить суспільству, i створення на цій основі ефективної системи державного управління [2, с. 4]. Дана реформа здійснюється кожного разу, коли існуюча система виконавчої влади об'єктивно не забезпечує належної організації виконання законів [3, с. 144], отже, можна констатувати, що станом на 2021 рік адміністративна реформа не тільки не втратила своєї актуальності, але й набула нового сенсу, оскільки «демократизація і гуманізація стосунків між виконавчою владою, іï посадовими особами, з одного боку, та громадянами, іншими приватними особами $€$ принциповим напрямком розвитку i вдосконалення системи виконавчої влади» [4, с. 285].

Для правильної періодизації звернемося для початку до Концепції адміністративної реформи (далі Концепція) - головного документу, що започаткував адміністративну реформу в Україні. Так, Концепцією визначено, що метою реформи є пое- 
тапне створення такої системи державного управління, що забезпечить становлення України як високорозвинутої, правової, цивілізованої європейської держави 3 високим рівнем життя, соціальної стабільності, культури та демократії, дозволить їй стати впливовим чинником у світі та Європі. İï метою є також формування системи державного управління, яка стане близькою до потреб і запитів людей, а головним пріоритетом іiі діяльності буде служіння народові та національним інтересам [5]. Отже, процес реформування було поділено на три етапи:

1. У ході підготовчого етапу реформи мали бути розроблені та офіційно схвалені Концепція адміністративної реформи та Програма здійснення адміністративної реформи. На цьому етапі розв'язуються першочергові питання, пов'язані з поточним удосконаленням елементів існуючої системи державного управління.

2. На другому етапі запроваджуються організаційно-правові засади реформування ключових елементів системи державного управління.

3. На третьому етапі поглиблюються трансформаційні процеси, формуються нові інститути, організаційні структури та інструменти державного управління. У контексті цього передбачається ряд перетворень у межах окремих інститутів виконавчої влади [5].

Крім цього, адміністративна реформа була поділена у своїй реалізації на декілька напрямів:

- перший - це створення нової правової бази, що регламентує державне управління в Україні;

- другий - це формування нових інститутів, організаційних структур та інструментів здійснення державного управління;

- третій - це кадрове забезпечення нової системи державного управління;

- четвертий - це зміцнення та формування нових фінансово-еко- номічних основ функціонування державного управління;

- п'ятий - це наукове та інформаційне забезпечення системи державного управління, формування механізмів наукового та інформаційного моніторингу іiі функціонування [5].

Отже, що таке адміністративна реформа? За своїм змістом адміністративна реформа $€$ комплексом узгоджених заходів, спрямованих на суттєве підвищення рівня керованості життєво важливих процесів у суспільстві шляхом науково обгрунтованого створення ефективного механізму державного управління, розвитку адміністративного законодавства, поліпшення кадрового, інформаційно-технічного і фінансово-економічного забезпечення організації виконавчої влади та місцевого самоврядування [6, с. 226].

Звернемося до етапів, які вже мали місце у вітчизняній адміністративній реформі:

1. 1995-2000 pp. - початок роботи в Комісії Верховної Ради над проектом Концепції адміністративної реформи, утворення Державної комісії з проведення в Україні адміністративної реформи, схвалення Концепції адміністративної реформи Президентом, розроблення теоретичних основ щодо проведення всіх складників адміністративної реформи. Так само для цього періоду є характерним прийняття законів «Про місцеві державні адміністрації [7] та «Про місцеве самоврядування в Україні» [8]; укази Президента щодо складу Уряду тощо;

2. 2001-2005 pр. - введення посад державних секретарів міністерств, скасування інституту державних секретарів міністерств, скасування урядових комітетів; запровадження посади Віце-прем'єр-міністра 3 адміністративної реформи, відновлення урядових комітетів; ліквідація посади Віце-прем'єр-міністра $з$ адміністративної реформи. Фактично даний період можна охарактеризувати як період становлення складників системи 
виконавчої влади та «пристосування» цих елементів до реальних умов;

3. 2006-2009 pр. - прийняття першого Закону України «Про Кабінет Міністрів України», активна діяльність Міністерства регіональної політики та будівництва щодо підготовки адміністративно-територіальної реформи. Розпорядженням Кабінету Міністрів України Міністерству юстиції України було доручено розробити законопроект «Про міністерства та інші центральні органи виконавчої влади».

4. 2010 р. - окремий етап проведення адміністративної реформи, що характеризується внесенням суттєвих змін до законодавства щодо організації системи органів виконавчої влади. Так, було прийнято новий Закон «Про Кабінет Міністрів України» [9]. Згодом було видано Указ Президента України «Про оптимізацію системи центральних органів виконавчої влади» [10], відповідно до якого стара система центральних органів виконавчої влади, що складалася з міністерств, державних комітетів та центральних органів виконавчої влади зі спеціальним статусом, припинила своє існування. На зміну державним комітетам прийшли служби, агентства та інспекції, а кількість центральних органів виконавчої влади зі спеціальним статусом було значно скорочено.

5. 2011-2013 рр. У 2011 році відбулося прийняття довгоочікуваного Закону України «Про центральні органи виконавчої влади» [11], який уперше за історію української незалежності на рівні закону визначив види центральних органів виконавчої влади, їх систему та компетенцію. У цьому ж 2011 році розпорядженням Кабінету Міністрів України було затверджено першу «Концепцію розвитку електронного урядування в Україні» [12], якою було визначено принципи функціонування системи електронного урядування та іiі складників і встановлено поря- док взаємодії органів публічної влади з громадянами за допомогою інформаційно-комунікаційних технологій для належного забезпечення прав і свобод людини і громадянина. Згодом на підтвердження існування «сервісної» складової частини державної політики у 2012 році було прийнято довгоочікуваний Закон України «Про адміністративні послуги» [13], який вперше на законодавчому рівні визначив поняття таких послуг, установив чіткий порядок їх надання і відповідальність органів державної влади за неналежне надання/ненадання таких послуг, а також було зазначено про перехід до повністю безпаперового надання адміністративних послуг, започатковано та створено Єдиний портал надання адміністративних послуг, що було безперечним кроком уперед у цифровій трансформації держави.

6. 2014-2017 pp. - етап адміністративної реформи, пов'язаний iз внесенням змін до Конституції України і приведенням у відповідність до Основного Закону держави всієї нормативно-правової бази, передусім тих законів та підзаконних актів, що стосуються організації системи органів виконавчої влади: прийняття Закону України «Про Кабінет Міністрів України» [14] тощо [15].

На цьому етапі необхідно окремо зазначити про започаткування та перші кроки щодо втілення масштабної адміністративно-територіальної реформи, визначену Концепцією реформування місцевого самоврядування та територіальної організації влади» в Україні [16]. Ця реформа, що триває і дотепер, формально вважається окремим процесом, не пов'язаним з адміністративною реформою, проте була зазначена в Концепції адміністративної реформи як іï складова частина, крім того, ці трансформаційні процеси є настільки взаємозалежними, що повністю відокремити одну від одної неможливо. Отже, всі етапи їх реалізації $€$ тісно пов'яза- 
ними між собою. Крім того, важливо зауважити, що саме поняття «адміністративна реформа» видається досить застарілим, оскільки акцентує увагу саме на управлінському базисі розглядуваного явища. I якщо врахувати тенденції останніх десятиліть щодо відходу від «управлінського» складника, уособленням чого є адміністративна реформа, до трансформацій більш демократичного характеру, то більш вдалим, мабуть, буде говорити не про «адміністративну реформу», а саме про «реформу публічної влади». I, як вбачається, реформа публічної влади є більш масштабним явищем, оскільки включає в себе не лише реформування системи органів державного управління (передусім органів виконавчої влади), а й системи органів місцевого самоврядування й інших суб'єктів. Крім того, варто звернути увагу, що адміністративна реформа характеризується не лише особливим суб'єктним складом, про який ми згадували. В адміністративній реформі важливою складовою частиною $€$ наявність передусім субординаційних зв'язків, тоді як у реформі публічної влади ми можемо говорити також про наявність координаційних та реординаційних зв'язків, зв'язки «нового рівня» та «нової якості» (насамперед ми маємо на увазі зв'язки між виконавчою владою і громадянами), тоді вживання застарілого терміна «адміністративна реформа» взагалі втрачає свою актуальність.

7. 2018-2021 - пропонується визначити як новий, «цифровий» етап адміністративної реформи, який відбувається під гаслом «електронна держава», коли діджиталізація та цифрові трансформації виходять за значенням на перший план. За цей період було видано декілька важливих актів у «цифровій» сфері, таких як нова Концепція розвитку електронного урядування [17]; Концепція розвитку цифрової економіки та суспільства України на 2018-2020 роки [18] тощо.
Важливо підкреслити, що цифровий етап втілення адміністративної реформи був закладений від самого ii початку. Так, Концепція визначила, що основними завданнями інформатизації державного управління було створення інформаційної системи державного управління; визначення потреб органів влади в нових інформаційних технологіях та базах даних; здійснення безпаперового документообігу; розроблення нормативно-правових актів з питань інформатизації адміністративної системи, в тому числі іï захисту [5]. Власне, це все і відображає всю сутність етапу цифровізації, який реформа переживає зараз, проте тоді, у 1998 році, це мало назву «інформатизація державного управління». Резюмуємо, що якісна реалізація адміністративної реформи $є$ абсолютно неможливою без належного застосування цифрових технологій: «...проведення адміністративної реформи має супроводжуватися цілеспрямованим застосуванням нових інформаційних технологій у сфері державного управління» [5].

Отже, цифровий етап адміністративної реформи, що триває сьогодні, $€$ важливим та всеохоплюючим, що засвідчують такі прийняті акти законодавства:

1. Нова Концепція розвитку електронного урядування [17] підкреслює, що повсякденне життя громадян стає все більш «цифровим», що передбачає високий рівень очікувань від діяльності органів влади, зокрема розвитку сучасних електронних форм взаємодіi,, прозорості та відкритості діяльності та залучення громадян до прийняття управлінських рішень;

2. Концепція розвитку цифрової економіки та суспільства України на 2018-2020 роки [18] чітко визначила основні цілі цифрового розвитку в економічний сфері;

3. Розпорядження Кабінету Міністрів України «Деякі питання реформування державного управління України» зазначає, що система елек- 
тронного документообігу та електронної взаємодії має бути єдиною так само, як веб-портали ОВВ, а також система надання адміністративних послуг, для чого і має бути створено єдиний профільний орган виконавчої влади у вигляді міністерства [19];

4. Постанова Кабінету Міністрів України «Деякі питання цифрового розвитку» [20] так само спрямована на підтримку цифровізації в Україні і має роз'яснювальний характер щодо державної політики цифрового розвитку;

5. Створення профільного провідного центрального органу виконавчої влади в зазначеній сфері - Міністерства цифрової трансформації - свідчить про пріоритетність розвитку цифрового урядування в контексті подальшого реформування системи публічного управління в Україні [21]. Створення профільного міністерства для формування державної політики у сфері цифровізації стало важливою віхою в напрямі до побудови цифрового урядування в Україні.

Цифрове урядування - це необхідність та виклик сучасності, а не просто намагання перейняти досвід найбільш розвинутих країн світу.

Основними аспектами цифрової трансформації, на які звертають нашу увагу міжнародні організації, $є$ :

- цифрова трансформація уряду в основному стосується трансформації управління та культурних змін на підтримку загального бачення і стратегії національного розвитку країни та досягнення Цілей сталого розвитку [22];

- цифрова трансформація уряду вимагає цілісного підходу, який інституціоналізується на всіх рівнях управління та суспільства. Це може бути реалізоване за допомогою плану, який включає проведення аналізу контексту та ситуації, формулювання спільного бачення трансформації уряду й того, як цифрові технології будуть використані для досягнення суспільних цілей, розроблення стра- тегії та цифрової дорожньої карти трансформації уряду і запровадження механізмів моніторингу та оцінки для постійного подальшого вдосконалення;

- цифрова трансформація уряду повинна бути спрямована на сприяння цифровій інклюзії та забезпечення того, щоб усі люди, включаючи вразливі групи, мали доступ до нових технологій для покращення свого добробуту. Це повинно ставити людей на перше місце й обертатись навколо їхніх потреб [23].

Однозначно можна визначити, що цифрове урядування, так само як й інші аспекти цифрових трансформацій, є невід’ємною складовою частиною сучасного етапу адміністративної реформи, яка триває, і виступає щодо неї, щонайменше, в трьох вимірах:

1. Як інструмент здійснення адміністративної реформи;

2. Одна з найважливіших цілей адміністративної реформи;

3. Показник ефективності як адміністративної реформи загалом, так і публічного управління на конкретному етапі зокрема.

Цифровізація нерозривно пов'язана 3 адміністративною реформою - як ії складник, мета та індикатор ефективності.

Сьогодні активний процес цифровізації вже давно $€$ не просто дороговказом, а цілком конкретною метою, більше того - життєвою необхідністю, на досягнення якої спрямовано чимало дій з боку держави.

Планомірність та послідовність втілення всіх етапів адміністративної реформи не тільки покращать та спростять щоденне «спілкування» між громадянами та державою, але й наблизять Україну за рівнем розвитку у сфері цифровізаціі до найбільш розвинутих країн, що $є$ безперечним позитивним аспектом у формуванні міжнародного іміджу нашої держави.

Отже, адміністративна реформа комплекс правових, організаційних, соціальних та інформаційних заходів, 
це здійснення системних трансформаційних змін, спрямованих на удосконалення системи публічного управління, що існує, та на досягнення комплексу цілей, зокрема соціальних, економічних, політичних тощо. Цифровізація сучасної системи публічного управління $€$ необхідністю для втілення всіх запланованих кроків.

Метою реформи є поетапне створення такої системи державного управління, що забезпечить становлення України як високорозвинутої, правової, цивілізованої європейської держави з високим рівнем життя, соціальної стабільності, культури та демократії, дозволить їй стати впливовим чинником у світі та Європі, системи управління, яка стане близькою до потреб і запитів людей, а головним пріоритетом їі діяльності буде служіння народові та національним інтересам [5]. Саме пріоритетність соціальних цілей має визначати спрямування реформи на іï конкретному етапі, адже за Основним Законом Україна є соціальною правовою державою і саме служіння суспільству $€$ ii основоположним напрямом діяльності держави. Варто розуміти, що адміністративна реформа не $€$ «одноразовим явищем», оскільки зачіпає всі аспекти функціонування держави на всіх рівнях - вид найвищого до найнижчого.

Як і будь-яке довготривале явище в державі, здійснення цієї реформи не могло не супроводжувати чимало проблем. Так, одна з головних проблем полягає в тому, що кожного разу під час реформування шляхом створення-реорганізації та ліквідації деяких вибіркових елементів системи органів наслідком $€$ непередбачувана ланцюгова реакція, яка вимагає на наступному кроці одночасного реформування інших елементів системи для відновлення так званої «управлінської рівноваги». Саме такі дії призводять до «нагальної необхідності проведення чергового етапу адміністративної реформи». Отже, реформування кожного елементу системи на кожному конкретному етапі має бути добре прорахованим i виваженим кроком.

Іншою проблемою ми можемо вважати те, що «адміністративна реформа в Україні значною мірою характеризується не суттєвими змінами в стилі роботи, а перейменуванням органів виконавчої влади, ліквідацією одних і появою інших, переливанням повноважень по рівнях управління, перестановкою і зміною керівників, збільшенням управлінського апарату за зменшення відповідальності органів і посадових осіб. У результаті цього управлінська система не змінює своїх параметрів і показників якості управління. При цьому слід ураховувати, що система виконавчої влади сьогодні реалізує свої управлінські функції не в стабільних умовах, а в умовах реформування суспільства, входження України в європейський і світовий правовий простір» [24].

Підсумовуючи вищевикладене, доходимо таких висновків:

1. Адміністративна реформа в Україні не лише не була завершена, а й перейшла на один із найважливіших етапів своєї реалізації - цифровий.

2. Цифровий етап адміністративної реформи був передбачений ще Концепцією, де зазначалося про «інформатизацію державного управління», що сьогодні $€$ аналогом «цифровізації публічної влади».

3. Цифровізація нерозривно пов'язана 3 адміністративною реформою - як їі складник, мета та індикатор ефективності.

4. Адміністративна реформа натепер має на меті остаточний перехід від принципу «управління заради управління» до принципу «держава для людини».

5. Адміністративна реформа та цифровізація нашої держави мають одну спільну мету - демократизацію відносин між громадянином і державою, в результаті чого належним

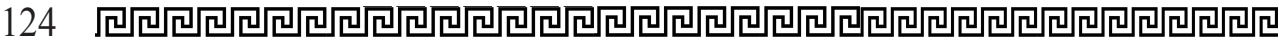


чином забезпечуватимуться права перших.

Отже, можна підсумувати, що цифрова трансформація держави сьогодні є не просто важливим досягненням для розвинутих, демократичних країн, а абсолютною необхідністю та вимогою сучасних реалій.

Адміністративна реформа в Україні - явище, значення якого важко переоцінити. Вже багато років, з моменту прийняття Конституції України, наша держава перебувае в стані постійного реформування. Ці трансформаиійні процеси охоплюють майже всі аспекти життедіяльності держави, а тому важливим є визначити, на якому етапі трансформаційних змін сьогодні знаходиться наша держава. У статmі проаналізовано визначення адміністративної реформи та вказано иілі й напрями, що були визначені кониептуальним документом - Концепцією адміністративної реформи. 3'ясовано, що адміністративна реформа, розпочата ще у 1997 роиі, не була закінчена, а лише перейшла на новий етап.

Автором визначено сім основних етапів реалізаціі адміністративної реформи. Основний акиент зроблено на останньому, сучасному - «цифровому» етапі. Проаналізовано законодавство, прийняте на кожному з етапів, а також вказано, які саме акти, що сприяли інформатизаиіі, було впроваджено. Вказано, щзо ицирровий етап проведення адміністративної реформи був закладений у Концепиію адміністративної реформи із самого початку, а застосування інформаиійно-комунікаційних технологій було визначено як абсолютно необхідний аспект здійснення такого реформування.

Автор акиентуе увагу на тому, що поняття «адміністративна реформа» $\epsilon$ досить застарілою як через неповний суб’єктний склад, так $i$ через те, що у класичній адміністративній реформі переважають зв'язки лише субординаційного характеру, що суперечить тендениіям з демократизації системи публінної влади останніх десятиліть. Отже, поняття "адміністративна реформа» нині потребує вдосконалення, тому пропонується замінити його більш сучасним терміном «реформа публічної влади».

Новий, циифровий етап адміністративної реформи характеризується передусім новим рівнем взаємодіі між державою та суспільством. Підкреслено, що адміністративна реформа $i$ ицирова трансформація держави насправді мають одну спільну мету. Так, втілення приниипу «держава для людини» повністю перекреслює усталений приници «управління заради управління», що $i \in$ одною з найважливіших иілей впровадження одночасно як ијифрових технологій у повсякденне життя, так $i$ адміністративної реформи.

Ключові слова: діджиталізація, адміністративна реформа, цифровізація, цифрові трансформації, цифрове урядування.

Mikhrovska M. DIGITAL TRANSFORMATION OF THE STATE AS A NEW STAGE OF ADMINISTRATIVE REFORM

Administrative reform in Ukraine is a phenomenon which importance is difficult to overestimate. For many years, practically since the adoption of the Constitution of Ukraine, our country is in a state of constant reformation. These transformation processes cover almost all aspects of the state' life. Therefore, it is important to determine at what stage of transformational change our state is today. The article analyzes the definition of administrative reform and indicates the goals in the areas defined by the conceptual document - 
the Concept of Administrative Reform. It turned out that the administrative reform, which began in 1997, was not completed, but only moved to a new stage.

The author identifies seven main stages of administrative reform. The main emphasis is put on the last, modern-"digital" stage. Thelegislation adopted at each stage, as well as the implemented acts that contributed to informatization is analyzed. It is underlined that the digital stage of administrative reform was included in the Concept of Administrative Reform from the very beginning, Moreover, the use of information and communication technologies was identified as an absolutely necessary aspect of such reform.

The author emphasizes that the concept of "administrative reform" is quite outdated both due to incomplete subject composition, and because the classical administrative reform is dominated by only subordinate relations. That on its turn contradicts with the trends of democratization of the public system of the latest decades. Thus, the concept of "administrative reform" today needs to be improved, therefore, it is proposed to replace it with a more modern term "reform of public power".

The new, digital stage of administrative reform is characterized, firstly, by a new level of interaction between the state and society. It is emphasized that administrative reform and digital transformation of the state, in fact, have one common goal. Thus, the implementation of the principle of "state for man" completely cancels the established principle of "governance for the sake of governance", which is one of the most important goals of the introduction of both digital technologies in everyday life and administrative reform.

Key words: digitalization, administrative reform, digital transformations, public authority reform, digital governance.

\section{Література}

1. Синергетичні засади державного управління в умовах реформ : монографія / ред. : С.М. Серьлгін. ДРІДУ НАДУ, 2007. 194 c.

2. Адміністративна реформа - історія, очікування та перспективи / ред. : В.П. Тимощук. Київ : Факт, 2002.

3. Пахомов I. Адміністративна реформа: як їі розуміти? Право України. 2001. № 3. C. 144-145.

4. Органи державної влади України / ред. : В.Ф.Погорілко. Київ : Ін-т держави і права ім. В.М. Корецького, 2002.

5. Про заходи щодо впровадження Концепиії адміністративної реформи в Україні (Указ Президента України). № 810/98. 1998. URL: https: / / zakon.rada.gov.ua/laws / show/810/98\#Text

6. Адміністративне право України. Академічний курс : підруч. : у двох томах / ред. : В.Б. Авер'янов. Київ : Юрид. думка, 2007. Том 1: Загальна частина.

7. Про місиеві державні адміністраиії: Закон України № 586-XIV. 1999. URL: https: / / zakon.rada.gov.ua/laws / show /586-14\#Text

8. Про місцеве самоврядування Закон України № 280/97BP. 1997. URL: https: / / zakon.rada.gov.ua/laws / show / 280/97-вp\#Text

9. Про Кабінет Міністрів України : Закон України № 2591-VI. 2010. URL: https: / / zakon.rada.gov.ua/laws / show / 2591-17\#Text

10. Про оптимізацію системи иентральних органів виконавчої влади : Указ Президента України № 1085. 2010. URL: https: / / wwr.reestrnpa.gov.ua/ REESTR/RNAweb.nsf / wpage/doc card? Open Document\&ID $=932922 \bar{E}$ E2F2 9D76BC22577F9002EED39

11. Про центральні органи виконавчої влади : Закон України № 3166-VI. 2011. URL: https: / / zakon.rada.gov.ua/laws / show/3166-17\#Text

12. Про схвалення Концепиії розвитку електронного урядування в Україні. Розпорядження Кабінету Міністрів України № 22250-p. 2010. URL: https: / / zakon.rada.gov.ua/laws / show /2250-2010-p\#Text

13. Про адміністративні послуги: Закон України № 5203-VI. 2012. URL: https: / / zakon.rada.gov.ua/laws / show/5203-17\#Text

14.Про Кабінет Міністрів України : Закон України № 794-VII. 2014. 


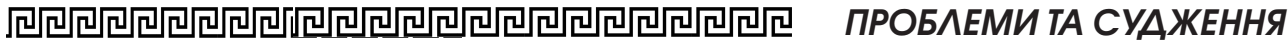

URL: https: / / zakon.rada.gov.ua/laws / show/794-18\#Text

15. Міхровська М.С. Адміністративна реформа в Україні: аналіз, періодизація, перспективи. Адміністративне право і проиес. 2014. Випуск 4 (10). С. 16-30.

16.Про схвалення Концепиіi ресормування місцевого самоврядування та територіальної організаціі влади. Розпорядження Кабінету Міністрів України № 333-p. 2014. URL: https: / / zakon.rada.gov.ua/laws / show/333-2014-p\#Text

17. Про схвалення Кониепиіі розвитку електронного урядування в Україні. Розпорядження Кабінету Міністрів України № 649-р. 2017. URL: https: / / zakon.rada.gov.ua/laws / show /649-2017-p\#Text

18. Концепція розвитку цииррової економіки та суспільства України на 2018-2020 роки. Розпорядження Кабінету Міністрів України № 67-р. 2018. URL: https://zakon.rada.gov.ua/laws / show/67-2018-p\#Text

19. Деякі питання реформування державного управління України : Розпорядження Кабінету Міністрів України № 474-р. 2016. URL: https: / / zakon.rada.gov.ua/laws / show /474-2016-p\#Text

20. Деякі питання иифрового розвитку : Постанова Кабінету Міністрів України № 56. 2019. URL: https: / / zakon.rada.gov.ua/laws / show/56-2019-n\#Text

21. Питання міністерства иифрової трансформащії : Постанова Кабінету Міністрів України № 856. 2019. URL:https: / / zakon.rada.gov.ua/laws / show/856-2019-n\#Text

22. Цілі сталого розвитку. URL: https: / / www.ua.undp.org / content / ukraine/uk/home/sustainabledevelopment-goals.html

$$
\text { 23. United Nations E-government }
$$
survey 2020. 2020.2 URL: https: / / publicadministration.un.org / egovkb/ Portals / egovkb / Documents / un / 2020 Survey / 2020\% 20UN\% 20E-Government $\% 20$ Survey\% 20(Full\% 20Report).pdf

24. Тодика Ю.м. Адміністративна реформа в Україні в аспекті розвитку конституиійного проиесу. Вісник Академії правових наук України. 2003. № 2 (33), 3 (34) URL: https: / / dspace.nlu. edu.ua/bitstream / 123456789 / 5787 / 1 / Toduka_224.pdf 